University of Nebraska - Lincoln

DigitalCommons@University of Nebraska - Lincoln

Publications, Agencies and Staff of the U.S.

Department of Commerce

U.S. Department of Commerce

2007

Evolutionary responses by native species to major anthropogenic changes to their ecosystems: Pacific salmon in the Columbia River hydropower system

Robin Waples

NOAA, robin.waples@noaa.gov

Richard W. Zabel

Northwest Fisheries Science Center, rich.zabel@noaa.gov

Mark D. Scheuerell

Northwest Fisheries Science Center, mark.scheuerell@noaa.gov

Beth L. Sanderson

Northwest Fisheries Science Center, Beth.Sanderson@noaa.gov

Follow this and additional works at: https://digitalcommons.unl.edu/usdeptcommercepub

Waples, Robin; Zabel, Richard W.; Scheuerell, Mark D.; and Sanderson, Beth L., "Evolutionary responses by native species to major anthropogenic changes to their ecosystems: Pacific salmon in the Columbia River hydropower system" (2007). Publications, Agencies and Staff of the U.S. Department of Commerce. 467. https://digitalcommons.unl.edu/usdeptcommercepub/467

This Article is brought to you for free and open access by the U.S. Department of Commerce at DigitalCommons@University of Nebraska - Lincoln. It has been accepted for inclusion in Publications, Agencies and Staff of the U.S. Department of Commerce by an authorized administrator of DigitalCommons@University of Nebraska - Lincoln. 


\title{
Evolutionary responses by native species to major anthropogenic changes to their ecosystems: Pacific salmon in the Columbia River hydropower system
}

\author{
ROBIN S. WAPLES, $\ddagger$ RICHARD W. ZABEL, ${ }^{*}$ MARK D. SCHEUERELL* and BETH L. SANDERSON† \\ *Fish Ecology Division, + Environmental Conservation Division, $\ddagger$ Northwest Fisheries Science Center, 2725 Montlake Boulevard East, \\ Seattle, WA 98112, USA
}

\begin{abstract}
The human footprint is now large in all the Earth's ecosystems, and construction of large dams in major river basins is among the anthropogenic changes that have had the most profound ecological consequences, particularly for migratory fishes. In the Columbia River basin of the western USA, considerable effort has been directed toward evaluating demographic effects of dams, yet little attention has been paid to evolutionary responses of migratory salmon to altered selective regimes. Here we make a first attempt to address this information gap. Transformation of the free-flowing Columbia River into a series of slackwater reservoirs has relaxed selection for adults capable of migrating long distances upstream against strong flows; conditions now favour fish capable of migrating through lakes and finding and navigating fish ladders. Juveniles must now be capable of surviving passage through multiple dams or collection and transportation around the dams. River flow patterns deliver some groups of juvenile salmon to the estuary later than is optimal for ocean survival, but countervailing selective pressures might constrain an evolutionary response toward earlier migration timing. Dams have increased the cost of migration, which reduces energy available for sexual selection and favours a nonmigratory life history. Reservoirs are a benign environment for many non-native species that are competitors with or predators on salmon, and evolutionary responses are likely (but undocumented). More research is needed to tease apart the relative importance of evolutionary vs. plastic responses of salmon to these environmental changes; this research is logistically challenging for species with life histories like Pacific salmon, but results should substantially improve our understanding of key processes. If the Columbia River is ever returned to a quasinatural, free-flowing state, remaining populations might face a Darwinian debt (and temporarily reduced fitness) as they struggle to re-evolve historical adaptations.
\end{abstract}

Keywords: dams, Darwinian debt, invasive species, migration, reservoirs, selective regimes

Received 1 March 2007; revision received 25 June 2007; accepted 18 July 2007

Introduction

Humans have altered natural ecosystems for many thousands of years, but the rate and magnitude of these changes have increased dramatically since the Industrial Revolution, such that humans now dominate all of the Earth's ecosystems (Vitousek et al. 1997). Deforestation, industrial agriculture, harvest, pollution, and urbanization are among the anthropogenic factors that have produced

Correspondence: Robin Waples, Fax: (206) 860-3335; E-mail: robin.waples@noaa.gov the most profound changes (Foley et al. 2005). In contrast to the attention that ecological responses to human disturbance have received, evolutionary consequences of these large-scale anthropogenic changes have been relatively neglected (Tseng 2007). The nature and magnitude of these evolutionary responses will be determined by interactions between the characteristics of the ecological changes and the biology and life history of the affected species.

Humanity already captures and uses more than half of the available fresh water on a global basis (Postel et al. 1996), largely through diversions and impoundments to 


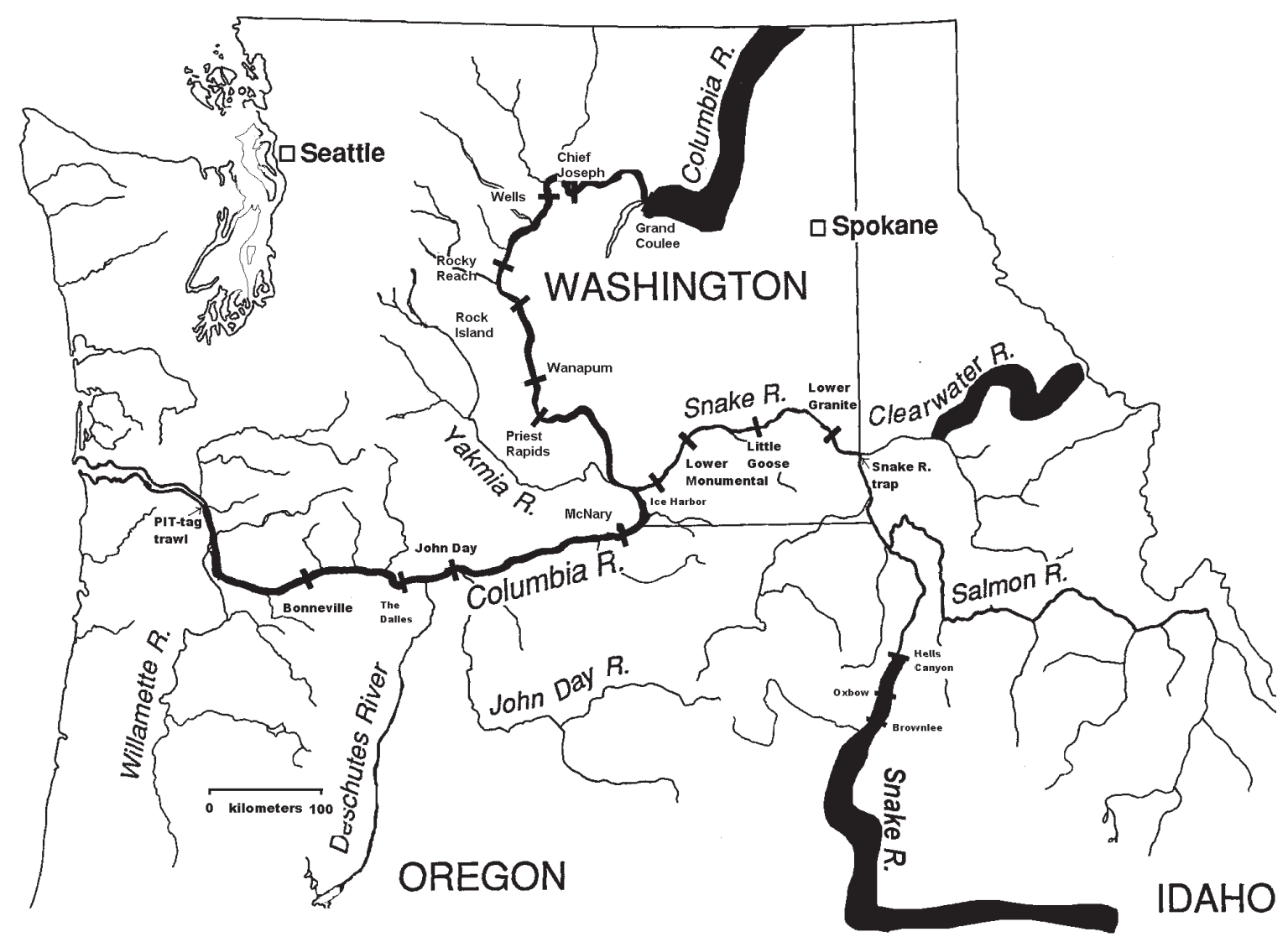

Fig. 1 Map of the Columbia River Basin showing mainstem dams on the Columbia and Snake Rivers. Shaded areas are historical habitats for salmon that are now inaccessible because of impassable mainstem dams. Celilo Falls (mentioned in the text), which historically was found just downstream of the mouth of the Deschutes River, was inundated in 1957 by the reservoir created by the Dalles Dam.

rivers (Vitousek et al. 1997). Major dams typically remain in place for decades to centuries, producing long-lasting changes to natural ecosystems. These effects are pervasive: approximately 40000 'large' (> $15 \mathrm{~m}$ tall) dams are in place worldwide (ICOLD 1998), and the vast majority of major rivers are impounded (McCully 2001). These impoundments have a particularly dramatic effect on the distribution, abundance, and life histories of migratory aquatic species (Merritt \& Wohl 2002).

Among the major rivers most profoundly affected by dams is the Columbia River in the northwestern USA, which drains an area the size of France. By 1900, hundreds of small dams had been built within the basin to transport lumber (Sedell \& Luchessa 1982) and supply water for municipal, industrial, irrigation, and livestock uses. Beginning in late 1800s, hydroelectric dams were constructed on larger tributaries. The Great Depression witnessed construction of federal hydropower projects of unprecedented size at Bonneville Dam and Grand Coulee Dam, to provide energy to fuel development of the interior Columbia River basin. Subsequently, nine more large dams were built between these structures on the Columbia, as well as four on the lower Snake River, the Columbia's major tributary (Fig. 1). Over 100 large hydroelectric and multipurpose dams currently exist within the basin (NRC 1996).

The Columbia River basin was, historically, also a major producer of Pacific salmon (Oncorhynchus spp.), supporting an estimated 8-10 million adults per year prior to European contact (NRC 1996). The rich diversity of salmon populations within the basin was forged during repeated Pleistocene episodes of glacial expansion and retreat and by more recent Quaternary events. A great deal has been written about, and a large amount of money spent on, the effects of the Columbia River hydropower system on Pacific salmon (e.g. NRC 1996; Dietrich 2003; Williams 2006). Mainstem dams have transformed a free-flowing river into a series of long lakes. Impassable dams preclude access of anadromous fish to $45 \%$ of their historical habitat area within the basin, and those dams with passage facilities present special challenges for both juvenile and adult migrations. Cumulative human impacts have depressed Columbia River salmon populations to the point that most are now listed as threatened or endangered under 
the US Endangered Species Act (see http://www. nwr.noaa.gov/ESA-Salmon-Listings/Salmon-Populations / index.cfm).

However, almost without exception evaluations of the effects of dams have focused on ecological/demographic consequences - for example, how many fish are killed by the hydropower system and how this affects population viability (Kareiva et al. 2000; Petrosky et al. 2001; McClure et al. 2003), and relatively little attention has been paid to evolutionary changes that the hydropower system is likely to elicit in salmon. In this respect, the situation in the Columbia River parallels the more general lack of attention to evolutionary changes associated with major anthropogenic rearrangements of ecosystems globally. This is a potentially serious omission, since ecological changes as pervasive as those caused by the Columbia River hydropower system are certain to profoundly alter the selective regimes that salmon experience, and some sort of evolutionary response is expected. What is not clear is how extensive these evolutionary changes might be and what their consequences would be for long-term viability.

In this study, we make a first attempt to examine evolutionary consequences of large dams for migratory fishes. It is a broad topic, so our treatment is necessarily somewhat superficial. First, we describe ecological/environmental changes associated with the Columbia River hydropower system, focusing primarily on mainstem dams on the Columbia and Snake Rivers. Next, we consider how these changes have altered selective regimes experienced by salmon and what types of evolutionary responses might be expected. Finally, we discuss the evolutionary challenges faced by Columbia River salmon in the broader context of what is known about evolutionary processes in other species, identify evolutionary considerations that will be particularly important to consider in salmon conservation and management, and outline research that could help to resolve critical uncertainties and increase our understanding of this complex topic.

\section{A short primer of salmon biology}

In this section, we emphasize factors important for evolutionary considerations; for more details about salmon biology and life history, see Groot \& Margolis (1991), Waples et al. (2001), Hendry \& Stearns (2004), and Quinn (2005). Five species of Pacific salmon occur in North America: pink salmon, Oncorhynchus gorbuscha; chum salmon, O. keta; coho salmon, O. kisutch; sockeye salmon, O. nerka; and Chinook salmon, O. tshawytscha. Steelhead, the anadromous form of rainbow trout (O. mykiss), is an honorary cousin to Pacific salmon; O. mykiss can spawn more than once, whereas the remaining species all die after spawning.

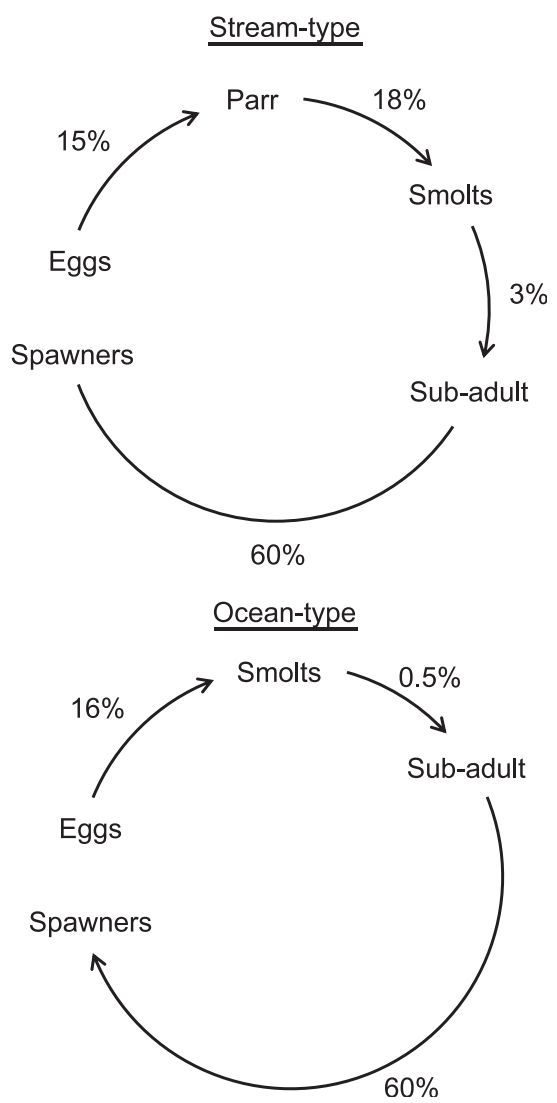

Fig. 2 Schematic life cycle diagrams for stream-type (yearling smolts) and ocean-type (subyearling smolts) Chinook salmon. Values shown are approximate survival rates for each life stage. Data sources: Kareiva et al. (2000); Greene \& Beechie (2004); Quinn (2005); Zabel et al. (2006); and B. Connor and J. Williams, unpublished.

Adults spawn in discrete freshwater locations, where juveniles rear for a period of weeks (pink and chum salmon), months (many Chinook and some sockeye populations), or a year or more (coho, steelhead, most sockeye, and some Chinook) before migrating to the sea. Most salmon spend 1-3 years (rarely more) at sea, where many populations make extensive migrations of several thousand kilometres. On reaching maturity, adults return to fresh water to spawn, generally in or near their natal stream. Strong sexual selection is generally associated with reproduction in the wild (Quinn 2005). Female salmon typically produce several thousand eggs, which provides ample opportunity for selective mortality associated with genetically based traits. Major episodes of mortality typically occur during egg development, juvenile rearing in freshwater, and in the first months of ocean residence (Fig. 2).

Cumulative evidence demonstrates the importance of local adaptation in Pacific salmon (reviewed by Taylor 1991). Data for sockeye, which exhibit migratory and 


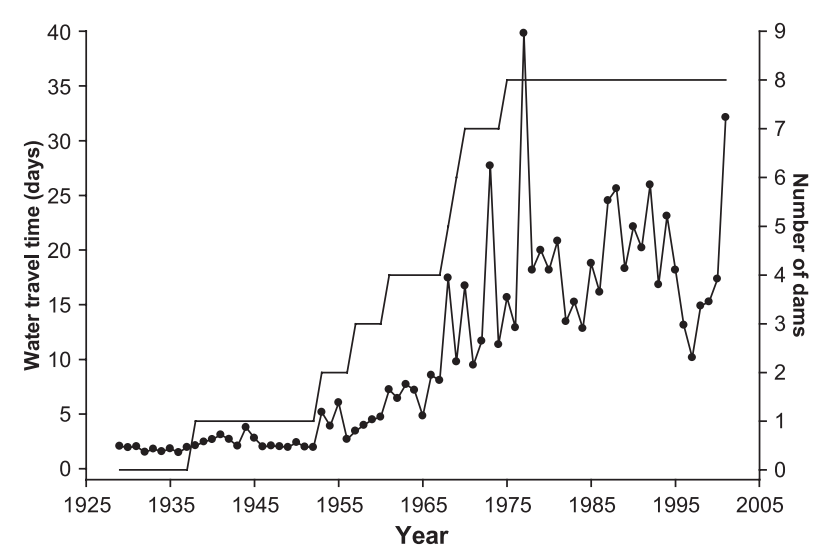

Fig. 3 Time required for an average water particle to travel from the confluence of the Clearwater and Snake Rivers to Bonneville Dam (circles) and the number of mainstem dams along the way (thick line) from 1929 to 2001 . Travel time estimates were calculated from average flows for the spring period 16 April-31 May. Source: NMFS Interior Columbia Technical Recovery Team, unpublished data.

nonmigratory forms, provide insight into underlying mechanisms. Populations of the nonmigratory form (kokanee) are ecologically exchangeable, as indicated by the high success rate $(\sim 90 \%)$ of transplantation attempts. In contrast, only three of over 80 attempts to transplant migratory sockeye have resulted in persistent populations, and each of the successes involved a translocation of less than $100 \mathrm{~km}$ (Wood 1995). This startling difference for two life-history types of the same species probably can be attributed to the much more complex life cycle of sockeye, which must execute a long series of changes with precise timing in order to complete their life cycle (Allendorf \& Waples 1996).

Historically, Chinook, coho, sockeye, and steelhead were well distributed throughout the Columbia River basin, whereas pink were rare or absent and chum were present mostly in lower river tributaries. Today, Chinook and steelhead are depressed but still widely distributed below impassable barriers; coho and chum are extinct upstream of Bonneville Dam; and most sockeye populations have been extirpated by anthropogenic factors. According to Gustafson et al. (2007), an estimated 55\% of historic Columbia River salmon populations have been extirpated, with values for individual species ranging from $40 \%$ in steelhead to $90 \%$ in sockeye. However, substantial components of ecological, genetic, and life-history diversity remain in the basin, especially for Chinook and steelhead. Some Columbia River populations are particularly distinctive. The Upper Salmon River in Idaho supports the highest spawning populations of Chinook, sockeye, and steelhead in the world ( $>2000 \mathrm{~m}$ above sea level altitude; $1500 \mathrm{~km}$ from the ocean). Steelhead populations east of the Cascade

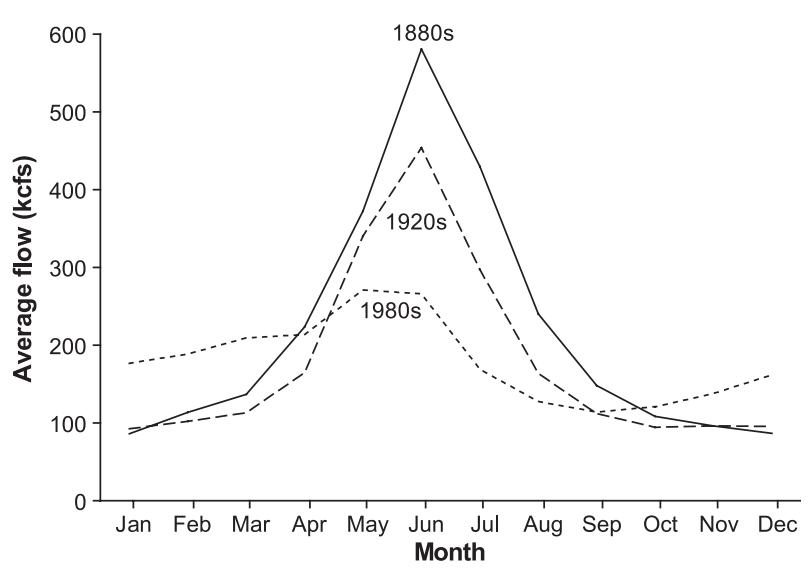

Fig. 4 Monthly average flow of the Columbia River measured at the Dalles ( $307 \mathrm{~km}$ from the sea) for three representative decades. Source: USGS National Water Information System (http://nwis.waterdata.usgs.gov/nwis).

crest are from a different subspecies than occurs on the coast, and interior Columbia and Snake populations of Chinook salmon are from two divergent lineages with distinctive genetic and life-history characteristics that behave effectively as separate biological species in areas where they are sympatric (Waples et al. 2004).

\section{Ecological changes associated with the hydropower system}

\section{Physical conditions}

River impoundments fundamentally alter flow by decreasing water velocity (Fig. 3), disrupting seasonal patterns with storage reservoirs (Fig. 4), and enhancing withdrawals for irrigation. Consequently, juvenile salmon now require substantially more time to migrate downstream through the Snake and Columbia Rivers (Raymond 1979). Furthermore, large pools upstream of dams have inundated historical spawning habitat, and, in some extreme cases, stretches of salmon-bearing streams are completely dewatered during the summer.

Changes in flow also affect thermal regimes by changing both mean water temperatures and the variance in temperature at several temporal scales (Steel \& Lange 2007). These effects are often exacerbated by loss of riparian vegetation (NRC 1996). Higher temperatures reduce growth efficiencies, which must be offset by higher consumption rates and greater prey production. Changes in water temperature also affect metabolic rates of salmon predators. Petersen \& Kitchell (2001) used a bioenergetics model to show that predation on juvenile salmonids in the mainstem Columbia River is $30 \%$ higher in periods of relatively warm water temperatures. 


\section{Water quality}

Hydropower development has promoted agricultural production, which diverts large amounts of water for irrigation. Only one-third of the water withdrawn from streams and lakes in the Pacific Northwest is ever returned (NRC 1995), and the water that does return is typically of poor quality, with lower dissolved oxygen and higher temperature, salinity, sediment loads, and contaminants from pesticides and fertilizers. These changes in water quality adversely affect development, growth, survival (Regetz 2003), susceptibility to disease, and the virulence of infection (Loge et al. 2005).

\section{Dam passage}

Impassable dams on the Upper Columbia (Chief Joseph/ Grand Coulee) and Snake (the Hells Canyon complex) preclude migratory access to thousands of kilometres of historical salmon-bearing streams, and remaining populations must pass up to nine dams during migration (Fig. 1). Although adult fish ladders were included in original designs for these lower river dams, juvenile seaward migration was largely ignored, with the result that young fish had to either pass through turbines or over the tops of dams through spillways. Studies documenting extremely high mortality during downstream migration (greater than $99 \%$ in some years; Williams \& Matthews 1995) prompted major changes, including large bypass screens, increased spill, and transportation of smolts through the hydropower system in barges. Survival of adults during upstream migration is generally high (for example, 80-90\% total survival through eight dams on the Columbia and Snake Rivers; Williams et al. 2005), but passage delays often occur at each dam as the fish seek a way through the turbulent tailraces. Median passage times are about 1 day per dam, but individuals can require a week or more to pass a single ladder (Keefer et al. 2004).

\section{Downstream effects}

Alteration of the magnitude and timing of river flow and the near elimination of flooding due to diking represent a fundamental shift in the physical state of the Columbia River estuary. Further, loss of connectivity among remaining habitats has restricted fish distributions and severely limited an important source of organic carbon for local food webs (Sullivan et al. 2001; Fresh et al. 2005). Dredging activity in the lower river to maintain shipping channels disturbs bottom sediments and affects the benthic fauna (McCabe et al. 1998). These factors also affect physical and biological characteristics of the offshore plume environment that are important to salmon growth and survival (de Robertis et al. 2005; Morgan et al. 2005; Emmett et al. 2006).

\section{Invasive species}

Along the Columbia and Snake River mainstems, juvenile and adult salmon consistently encounter 20-40 non-native fish species, particularly in reservoirs (which facilitate the spread of non-native species as well as the expansion of native populations suited to these lotic environments; Havel et al. 2005). In Columbia River reservoirs, introduced walleye (Sander vitreus) and smallmouth and largemouth bass (Micropterus dolomieu and Micropterus salmoides, respectively) consume hundreds of thousands of juvenile salmon annually and up to $35 \%$ of the juveniles in some populations (Rieman et al. 1991; Fritts \& Pearsons 2004). Non-native taxa are also broadly established in salmon spawning and rearing habitats of most Columbia River Basin tributaries.

Non-native species function in aquatic and terrestrial food webs as predators and competitors for food and space. For example, each year an estimated 2-4 million adult American shad (Alosa sapidissima) pass through Bonneville Dam between May and July, making this introduced Atlantic species the most abundant anadromous fish in the Columbia River Basin. Non-native species have also affected Columbia River communities via habitat alteration, by facilitating transmission of disease, and through hybridization with native taxa.

\section{Predator/prey interactions}

Reservoirs and islands formed by dredged spoils have facilitated population explosions of native Northern pikeminnow (Ptychocheilus oregonensis) and Caspian tern (Sterna caspia). Control measures have been implemented for both species to limit predation on juvenile salmon (Strauss et al. 2006). The tern population in the lower river grew from zero to over 7000 breeding pairs during 1980-2000 (Suryan et al. 2004) and in 1998 consumed an estimated 9.1-15.7 million juvenile salmonids in the Columbia River estuary (Roby et al. 2003).

\section{Evolutionary consequences for salmon}

Evolutionary changes require genetic variation in a heritable trait. Narrow-sense heritability $\left(h^{2}\right)$ quantifies the fraction of trait variation attributable to genetic (as opposed to environmental) factors. A number of morphological, physiological, and life-history traits in Pacific salmon show relatively high heritabilities, including: growth rate ( $\left.h^{2}=0.1-0.8\right)$, tolerance to high temperature (0.48), egg number (0.16-0.67), and various meristic traits (0.4-0.9) in rainbow trout (Hallerman 2003); precocious male maturation (0.1-0.5; Heath et al. 1994), age at maturity (0.2-0.6; Hankin et al. 1993; Hard 1995, 2004), growth rate (0.3; Hard 2004), and disease resistance (up to 0.8; Beacham \& Evelyn 
1992; Hard et al. 2006) in Chinook salmon; and spawn timing in various species (0.2-0.5; Hard \& Hershberger 1995; Hard 2004). Studies of Chinook salmon transplanted to New Zealand have also found high heritabilities for timing of maturation (Quinn et al. 2000), egg size (Kinnison et al. 2001), and secondary sexual characteristics (Kinnison et al. 2003). Collectively, these data suggest that evolutionary responses to the types of altered selective regimes produced by the Columbia River hydropower system can be expected. Below we describe the types of evolutionary pressures associated with the Columbia River hydropower system, organized by life stage to facilitate comparison with the generalized salmon life cycle shown in Fig. 2.

\section{Egg-juvenile phase}

Columbia River salmon typically experience high mortality during juvenile rearing stages (Fig. 2), which provides ample opportunity for an evolutionary response. Within populations, size-selective mortality is strong during this phase, perhaps related to the establishment of social hierarchies (Zabel \& Achord 2004). Although direct effects of the hydropower system on these life stages are probably minimal in many populations, the condition of juveniles as they enter the hydrosystem and their migrational timing determine their success in later life stages, as described below. In addition, some populations, such as Snake River fall Chinook salmon, spawn and rear below dams, and their survival is affected by regulated river flow and temperature (Smith et al. 2003).

Passage at the dams. The large ( $30 \mathrm{~m}$ high) mainstem dams create strong selective pressures for fish that have the ability to navigate through, around, or over the concrete structures. Juveniles have at least three passage options at each dam: over the spillway, through the turbines, or through a juvenile bypass system. Each dam passage scenario poses different survival probabilities and selective pressures for juvenile salmon, and the fraction using each option depends on fish size (Zabel et al. 2005). Juveniles migrating over spillways typically survive at higher rates than those passing through turbines or bypass systems (Ferguson et al. 2005), and they also spend less time in the area near the dam, where predator densities are high (Ward et al. 1995). The array of juvenile passage scenarios guarantees that each year, different individuals within populations, and different populations within species, experience diverse selective pressures as they migrate downstream.

Transportation. In addition to the three bypass options, juveniles can be collected at a dam and transported downstream in a barge or truck to the area below Bonneville Dam. In some years, as many as $99 \%$ of the juveniles of some species are transported (Williams et al. 2005). This practice creates an entirely different selection regime compared to that experienced by in-river migrants. Nearly all transported fish survive to release below the hydrosystem, whereas their counterparts that migrate in-river typically suffer $50 \%$ mortality (Williams et al. 2005). However, post-release survival of transported fish is often much reduced (for Snake River spring and summer Chinook salmon, approximately half that of fish that arrived below the hydrosystem via in-river migration; Williams et al. 2005). The result of these management practices is a large difference in the amount of time it takes juveniles of the same species to reach the estuary: in-river migrants require 2-6 weeks to migrate through the hydrosystem, while transported fish arrive at the same destination in 2 days (Muir et al. 2006).

Competition and predation. Although evolutionary responses of Pacific Northwest salmonids to the presence of nonnative species have not been investigated, such responses are well documented for a range of other taxa (Cox 2004; Straus et al. 2006). In particular, we might expect the following responses to novel predation pressures on juvenile salmon: use of alternative habitats, which might be suboptimal with respect to temperature, flow, and food resources; shifts in diet; increased escape or avoidance responses, which can be energetically costly; and altered migration timing. The Northern pikeminnow and Caspian tern, whose predation rates on juvenile salmon have skyrocketed in recent years because hydrosystem changes have created favourable foraging opportunities, are known to be size-selective predators. Pikeminnow favour smaller juvenile salmon (Muir et al. 2006), whereas terns preferentially select larger fish for their own consumption but smaller fish when feeding their young (Anderson et al. 2005). Peak tern colony occupancy in the lower Columbia River is late May, which would tend to favour juveniles migrating either earlier or later in the season.

\section{Early ocean phase}

Juvenile migration of salmon in the Columbia River basin is so dramatically changed from historical conditions that, in addition to direct mortality, sublethal effects are expected. These effects (stress, injury, and disrupted migration timing) can be manifest as latent mortality later in the life cycle (Williams et al. 2005) - especially in the early ocean phase, which typically involves high natural mortality (Fig. 2).

Size and condition. Size and condition are crucial factors in determining survival of juveniles, as they must successfully forage and grow rapidly to minimize the time they are small enough to suffer high predation rates. Selection 
coefficients for size of juvenile Chinook salmon entering the hydropower system are extremely high when compared to other taxa in other systems (Zabel \& Williams 2002). In addition, in-river migrants grow an average of $6-8 \mathrm{~mm}$ in length during downstream migration, while transported fish have negligible growth (Muir et al. 2006). As a consequence, the two groups differ in size and susceptibility to the suite of predators awaiting them in the estuary (Muir et al. 2006).

Migration timing. The timing of life-history events is often a critical component of fitness, particularly for migratory species. Timing of juvenile migration is heritable in salmon (Taylor 1990, 1991), and Pearcy (1992) suggested that salmon might adapt their seaward migration timing to exploit optimal conditions (temperature, feeding opportunities or predator avoidance) during river migration and ocean entry. For spring migrants (steelhead and streamtype Chinook), survival during migration through the reservoirs decreases with increasing temperature (Williams et al. 2005), which typically increases during the migration season. Thus, current conditions favour early migrating fish within populations, as well as populations that on average migrate earlier in the season. However, development of hydroelectric dams has slowed downstream migration of juvenile Chinook salmon by approximately 2 weeks (Raymond 1979). This entails a substantial fitness cost when the fish reach the ocean, as those migrating later in the season have reduced survival to adulthood (Zabel \& Williams 2002; Williams et al. 2005; Fig. 5).

\section{Adult migration phase}

Adult salmon no longer have to swim hundreds of kilometres upstream against a strong current on their spawning runs, which presumably has resulted in relaxation of selection for traits such as swimming endurance, fusiform body shape, and a high body fat content to fuel the migration; (Crossin et al. 2004). Historically, Celilo Falls in the Columbia River Gorge represented a major challenge to anadromous adults and would have eliminated from the breeding population fish incapable of surmounting the cataract. Native Americans annually set up fishing camps at the falls to harvest salmon as they made their way up the few viable routes, but these fishing opportunities, and the evolutionary challenge they posed to salmon, were eliminated when the falls were inundated by the reservoir created by the Dalles Dam in 1957.

Adult fish ladders generally operate effectively enough to avoid large direct mortality of migrating salmon, but they still can exert considerable selective pressures. Salmon are justifiably renowned for their homing ability and acute sense of olfaction, but to successfully pass upstream through today's hydropower system, they must now be able to
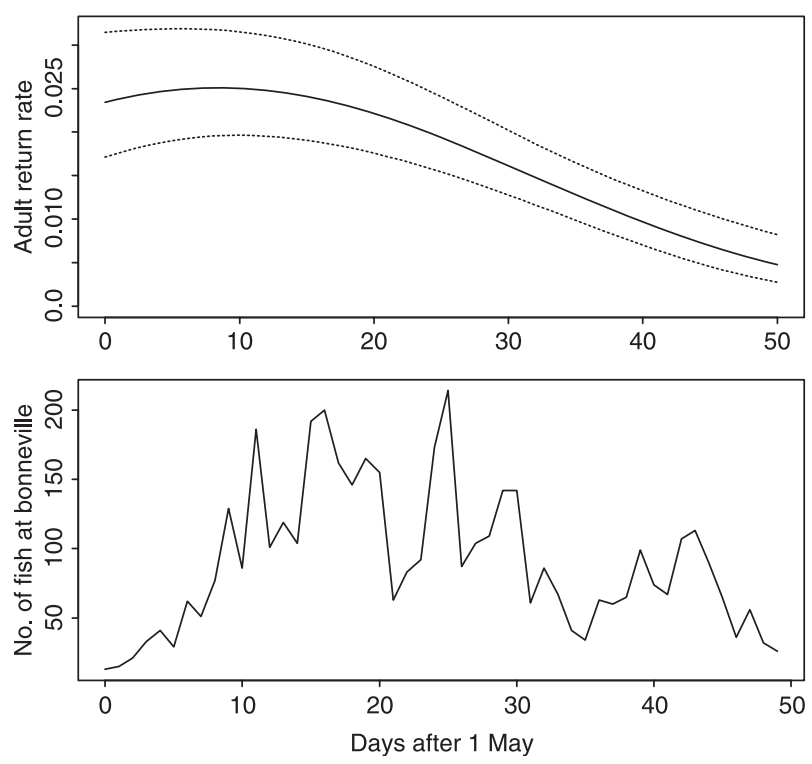

Fig. 5 Top: probability of adult return to Lower Granite Dam vs. juvenile arrival date to the estuary (below Bonneville Dam) for Snake River spring/summer Chinook salmon. Solid line is logistic regression; dotted lines are 95\% confidence intervals. Analysis based on unpublished data for 4538 juveniles tagged with unique codes in 2002. Bottom: distribution of arrival time at Bonneville Dam in 2002 of tagged juveniles representative of the population as a whole.

detect relatively weak outflows associated with adult fish ladders amidst the turbulence below mainstem dams - a challenge they have never had to meet in their severalmillion-year evolutionary history.

For adults, even short delays finding each ladder can be costly. Adult salmonids cease feeding during their upstream migration and thus rely on energy reserves to carry them to spawning grounds. Extensive delays at dams can result in the depletion of these reserves (Geist et al. 2000), and fish that take longer to pass dams are less likely to successfully complete their migration (Caudill et al. in press). When migrating adult salmon encounter warm water temperatures $\left(>20^{\circ} \mathrm{C}\right)$ in mainstem reservoirs, which often occur later in the migration season, they often take refuge in cooler tributaries (High et al. 2006). This has the effect of further delaying migration and might affect ultimate homing accuracy (although the latter has not been empirically demonstrated).

\section{Reproduction}

In addition to delays and mortality associated with adult dam passage, the Columbia River hydropower system has other indirect effects on reproduction in salmon populations. Pristine populations of Pacific salmon at or near carrying capacity undergo intense sexual selection on the spawning grounds (Quinn 2005). By dramatically 
reducing population abundances, dams and other anthropogenic activities have diminished competition and sexual selection during reproduction.

\section{Effects across multiple life stages: cost of migration}

Migration entails evolutionary costs (mortality, energy expenditure), so migratory life histories will be favoured only if these costs are offset by increased survival and growth in the habitat accessible as a result of migration (Gross 1987; Roff 1988). Hydroelectric development in the Columbia River basin has increased the cost of migration for salmon populations, and this should make conditions more favourable for nonmigratory forms. More pervasive effects are likely for Oncorhynchus mykiss and Oncorhynchus nerka, which are characterized by the existence of multiple evolutionarily stable states; both species have numerous nonmigratory as well as anadromous populations (Hendry \& Stearns 2004). In O. mykiss in particular, anadromous steelhead provide the evolutionary glue that connects populations by occasional gene flow and ensures that they follow a common evolutionary trajectory. Steelhead tend to cease migration in reservoirs when water temperature exceeds approximately $13{ }^{\circ} \mathrm{C}$ (as often occurs later in the migration season; Williams et al. 2005), which can lead to disruptive selection favouring either early migration or adoption of a nonmigratory life history.

The cost of migration also has important consequences for the expression of multiple spawning in O. mykiss. Repeat spawners undergo a seaward migration shortly after they spawn in the spring. This seaward migration of adult steelhead through the Columbia River hydropower system is extremely risky under current conditions (> 99\% mortality; Ferguson et al. 2005), which should provide strong selection toward semelparity. Finally, increasing the cost of migration can change the balance between natural and sexual selection. As migration becomes more arduous, individuals have less energy to devote to secondary sexual characteristics (Kinnison et al. 2003), which further reduces the strength of sexual selection beyond the effects noted above related to reductions in population size.

\section{Collateral damage}

The sections above consider changes to salmon ecosystems directly caused by hydropower operation. For completeness, we include here a brief summary of two other important agents of evolutionary change that are indirectly associated with hydropower operation: harvest and hatcheries.

Even in the 1930s, it was apparent to fishery managers that construction of mainstem dams would have serious impacts on salmon populations. One tangible response to these concerns was passage of the Mitchell Act (US Public Law 75-502; 1938), which mandated construction of hatcheries to compensate for losses of natural populations. Additional 'mitigation' hatcheries accompanied construction of subsequent mainstem dams in the Columbia and Snake Rivers. Over the past decade, Columbia River basin salmon and steelhead hatcheries have released over 100 million juvenile salmon each year into streams, where they interact ecologically and genetically with wild populations. Evolutionary consequences of salmon hatcheries have received far more attention than other anthropogenic factors (see Waples \& Drake 2004 and Mobrand et al. 2005 for discussions).

Management of mitigation hatcheries has been inextricably intertwined with management of fisheries to harvest hatchery-produced fish. These fisheries typically occur at sea or in the mainstem, where fish from many different populations commingle and are harvested in mixed-stock fisheries. Harvest management attempts to 'shape' the harvest toward certain times and localities, which can exert substantial selective pressures for or against certain populations or behaviours. In addition, many of the fisheries either actively or passively select for larger fish, which creates a selection gradient for traits related to size (e.g. growth rate and age at maturity). Recently there has been some interest in the evolutionary consequences of harvest, both in salmon (Hard 2004) and other species of fish (Conover \& Munch 2002; Hutchings 2005).

\section{Synthesis and conclusions}

Two conclusions are readily apparent from material presented above. First, selective regimes experienced by Pacific salmon have been profoundly altered by the Columbia River hydropower system. Second, there is a strong heritable component to many of the traits that would be expected to be under strong selection as a result of these environmental changes. However, evaluating the actual evolutionary responses by salmon populations, and what this ultimately means for long-term sustainability, is much more complicated. To begin to address these issues, we first review some general evolutionary considerations and then turn to discussing data for salmon.

Abundant empirical evidence documents the reality of contemporary microevolution in natural populations (including Pacific and Atlantic salmon), but very strong directional selection is seldom observed (Kingsolver et al. 2001; Kinnison \& Hendry 2001). Merilä et al. (2001) discussed a number of reasons why this might be the case. First, perhaps no evolution has actually occurred. Heritability of the trait(s) under consideration might be overestimated, or selection might be acting on a nonheritable part of the phenotype. Second, evolution might be occurring but its action masked by confounding factors. 
For example, because of genetic correlations among selected traits, in some cases evolution of bill size in Galapagos finches occurred in the opposite direction to that predicted (Grant \& Grant 1995). Only a few studies (e.g. Hard 2004) have measured genetic correlations among life-history traits in Pacific salmon. Alternatively, the species might have evolved (changed its norm of reaction) just to maintain the same phenotype in an altered environment. Or, selection might be variable in space and/or time, so that the net evolutionary response is modest. Finally, statistical power might be insufficient to detect any but the most pronounced evolutionary changes.

We can conclude from the above that the evolutionary responses of Pacific salmon to ecosystem changes caused by the Columbia River hydropower system will be difficult to predict and challenging to measure. For example, several different factors exert selective pressures for juvenile migration timing (growth rates; predation pressure in freshwater; marine conditions), and these factors do not necessarily all act in the same direction. This might help explain the apparent disconnect between the optimal time of arrival at the estuary of juvenile Chinook salmon and the observed time (Fig. 5). In spite of apparently strong selection for early migration timing, these populations might find it difficult to compensate for dam-related delays by an evolutionary response. Attaining a critical size appears to be a trigger for initiation of seaward migration (Achord et al. 2007), and there is evidence that larger size at migration is also strongly selected for (Zabel \& Williams 2002). Thus, an evolutionary shift to earlier migration timing might also require evolution of a higher growth rate. Although growth rate in Chinook salmon is heritable $\left(h^{2}=0.3\right.$; Hard 2004), increasing growth rates typically involve trade-offs with other fitness-related traits (Conover \& Schultz 1997; Hard 2004).

Dams have their most dramatic and direct effects on the juvenile and adult migratory phases; in both cases, genotypes favoured under current conditions differ considerably from those favoured in pristine river systems. However, we have also seen that, indirectly, dams can produce an evolutionary response that is expressed at a different life stage (e.g. by increasing the cost of migration, which reduces energy available for sexual selection and increases the relative fitness of the nonanadromous life history). These general themes are broadly relevant to investigations of the evolutionary effects of dams on migratory species on a global scale.

An unusual, local twist is that current operation of the Columbia River hydropower system ensures that each year, some juveniles migrate downstream through all the dams, while others from the same population are transported in trucks or barges. As we have seen, the two groups of fish have different mortality rates while in the rivers and, presumably, during their early ocean residence. This repeated partitioning of a single population into components with different demographic trajectories is analogous to what occurs in a natural population subjected to hatchery supplementation (Waples \& Drake 2004). Under these conditions, it can be very challenging to determine the net effects of selection within the population. A related phenomenon (and additional complexity) is that ecological changes create novel selective pressures not only among individuals within populations, but also among populations within species.

Although this topic is challenging and has been relatively neglected for a long time, a number of things can be done to help advance our understanding of the evolutionary responses of Pacific salmon to anthropogenic chan-ges, including those associated with the Columbia River hydropower system. Estimates of heritabilities can be obtained for more traits in more species, if possible in natural populations using modern molecular methods of parentage analysis. The potential upward bias in estimated heritabilities noted by Merila et al. (2001) can be addressed in part by more fully accounting for maternal effects in quantitative genetic studies.

Experiments to elucidate the genetic architecture (genegene correlations) of the target species are important to fully understand the effects of natural selection, which (except in simple computer models) seldom operates on a single trait. However, these evaluations can be complicated by evolution of the genetic covariance matrix itself. The evolutionary response of salmon to environmental change cannot be understood without also understanding the capacity of the species for phenotypic plasticity (expression of multiple phenotypes with the same genotype). The range of phenotypes expressed is known as the norm of reaction (Hutchings 2004), and reaction norms can be characterized by common-garden experiments. All of these approaches are challenging to implement with nonmodel species, especially those (such as Pacific salmon) that are age-structured, have a relatively long generation time (which typically equals or exceeds the experimental time available for a doctoral thesis), and spend half or more of their life in the highly unpredictable marine environment. Implementing some of these approaches, however, can provide vital information for conservation and management of migratory species such as salmon.

\section{Climate change}

Evidence is beginning to accumulate showing an evolutionary response by species to recent climate change (Bradshaw \& Holzapfel 2006). Theoretical considerations and empirical results indicate that natural populations are capable of relatively rapid evolution (0.1-0.5 standard deviation of trait value per generation) over short time periods (tens or hundreds of generations), but the rate that 
natural populations can sustain for long periods of time is much lower (a few per cent standard deviation change in a trait per generation) (Kinnison \& Hendry 2001).

Climate changes have important consequences for Pacific salmon and will interact synergistically with direct environmental effects of dams to determine the nature and extent of evolutionary responses by salmon. Some consequences are predictable in a general way (Mote et al. 2003): warming trends will shift precipitation toward winter rains rather than snow, and reduced snowmelt will produce earlier peak flows and less cool water in summer, when elevated stream temperatures can approach the thermal tolerance for salmon. Higher water temperatures will mean higher metabolic rates for juvenile salmon, as well as higher consumption rates for predators. Warmer thermal regimes might also promote the evolution and spread of infectious diseases, as well as the virulence of disease outbreaks.

In response to these new challenges, Columbia River salmon populations will have four options: (i) express a different phenotypic without any genetic change (phenotypic plasticity); (ii) evolve a different phenotype; (iii) move to a new location more compatible with their existing phenotype and life history; or (iv) go extinct. We know that salmon can express plasticity for key life-history traits (Beckman \& Dickhoff 1998), are capable of relatively rapid evolution in novel environments (Quinn et al. 2001), and can in some cases rapidly colonize newly accessible habitat (Milner 1987). We also know that salmon populations can go extinct - the fate of perhaps $30 \%$ of historic populations in the contiguous USA. (Gustafson et al. 2007). However, we still have a lot to learn before we have a sound basis for predicting which of these scenarios is most likely in any given circumstance.

\section{Sustainability}

A key question for management and conservation is, 'What do evolutionary changes associated with the hydropower system mean for long-term sustainability of salmon in the Columbia River?' Some general insights into this complex question can be gained by simple models of populations challenged by environmental changes. Because adaptation requires genetic deaths that result from the action of natural selection, populations experiencing rapid environmental changes often are in a race to adapt before they go extinct (Burger \& Lynch 1995; Gomulkiewicz \& Holt 1995). These studies show that the mean population phenotype typically evolves in parallel with, but lags behind, the optimum, and the magnitude of the lag is a crucial factor determining extinction risk. Figure 5 provides evidence of a lag of this type in timing of arrival of juvenile Chinook salmon to the estuary. In addition, random demographic and genetic events considerably increase extinction risk in small populations, so populations that have been reduced in size by anthropogenic factors are particularly vulnerable when challenged by rapid environmental changes. Both of these factors constrain the maximum sustained rate of evolution that a population can withstand. For Pacific salmon, two additional issues are particularly important for sustainability.

Biocomplexity. Although it is axiomatic that biocomplexity contributes to sustainability, empirical demonstrations of this ecological principle in natural systems are rare. Perhaps the best example involves sockeye salmon in Bristol Bay, Alaska, which have supported harvests on the order of 10 million fish per year for over a century, in spite of large changes in the proportional contribution of different stock complexes to the harvest (Hilborn et al. 2003). That is, overall abundance and productivity is more robust than any of the contributing components. Over longer time frames, the rich store of adaptive diversity expressed by Bristol Bay sockeye salmon provides the raw material upon which future evolution can act and the resilience to meet future environmental challenges. Impassable dams have already extirpated many salmon populations and life history types in the Columbia River basin (Bottom et al. 2005; Gustafson et al. 2007). If current conditions associated with hydropower development select for a narrower range of phenotypes than what has occurred historically, biocomplexity (and prospects for long-term sustainability) will be reduced. More study is needed to determine to what extent this might be true.

Darwinian debt. Evidence that fish populations have evolved maladaptive traits in response to size-selective harvest has led to the concept of a Darwinian debt, which must be repaid by further evolution before the population can restore its lost fitness (Walsh et al. 2006). This concept is also more broadly relevant to conservation of salmon in the Columbia River basin. Although it is difficult to predict the exact nature of evolutionary responses by salmon to altered environments, such responses are inevitable given the profound changes to selective regimes and mortality profiles. Even dams as massive as those in the Columbia River have a finite useful life of only a century or two, which represents the blink of an eye on evolutionary and geological timescales.

What might be the evolutionary consequences for salmon of returning the Columbia and Snake Rivers to more natural conditions (Williams 2006)? This would presumably restore selective regimes to something approaching historical patterns. However, to the extent that salmon have adapted to the radically altered ecological conditions of the current hydropower system, we might expect a rocky period of adjustment during which the populations have to repay the Darwinian debt they accrued by re-evolving adaptations to the restored natural conditions. Juveniles adapted to surviving spillways, turbines, diversion channels, and transportation in barges would have to re-evolve skills 
to navigate down the mainstem Columbia River at peak flows. Adults selected for the ability to navigate fish ladders and migrate through slack-water reservoirs might suddenly find they had insufficient energy reserves to migrate hundreds of kilometres upstream against strong currents and insufficient strength to surmount the renascent Celilo Falls. Timing of migration and other key life- history traits that had evolved in response to hydropower changes might be maladaptive in the new (old) environments. Thus, it is reasonable to expect that at least temporary reductions in fitness due to a Darwinian debt would accompany restoration of normative river conditions. With luck, the immediate reductions in direct mortality associated with the hydropower system would more than offset the interest on the Darwinian debt. It is not hard to imagine, however, that at least some populations might find themselves in a desperate race to re-evolve historical traits before they go extinct.

Although we have focused on Pacific salmon in one major river basin in the western USA, we expect that similar ecological and evolutionary considerations apply to Atlantic salmon (Salmo salar) in eastern North America and Europe, where dams also are a common feature of river ecosystems. More broadly, migratory fishes are of particular conservation concern on a global scale (e.g. McDowall 1999). Understandably, most conservation attention has focused on the extremely depressed population sizes of many migratory species. However, our analyses suggest that the nature and scale of ecosystem changes associated with large dams has the potential to elicit strong evolutionary responses in affected populations, and it will be difficult to craft effective, long-term conservation strategies without a better understanding of these contemporary evolutionary processes.

\section{Acknowledgements}

We thank Sonia Sultan for stimulating discussions, Jeff Hard for providing data on heritability of life-history traits in salmon, John Williams for Fig. 1, and John Ferguson, Mike Kinnison, and two anonymous reviewers for useful comments that substantially improved the manuscript.

\section{References}

Achord S, Zabel RW, Sandford BP (2007) Migration timing, growth, and estimated parr-to-smolt survival rates of wild Snake River spring-summer Chinook salmon from the Salmon River basin, Idaho, to the lower Snake River. Transactions of the American Fisheries Society, 136, 142-154.

Allendorf FW, Waples RS (1996) Conservation and genetics of salmonid fishes. In: Conservation Genetics: Case Histories from Nature (eds Avise JC, Hamrick JL), pp. 238-280. Chapman \& Hall, New York.

Anderson SK, Roby DD, Lyons DE, Collis K (2005) Factors affecting chick provisioning by Caspian terns nesting in the Columbia River estuary. Waterbirds, 28, 95-105.
Beacham TD, Evelyn TPT (1992) Population and genetic variation in resistance of Chinook salmon to vibriosis, furunculosis, and bacterial kidney disease. Journal of Aquatic Animal Health, 4, 153-167.

Beckman BR, Dickhoff WW (1998) Plasticity of smolting in spring Chinook salmon: relation to growth and insulin-like growth factor-I. Journal of Fish Biology, 53, 808-826.

Bottom DL, Simenstad CA, Burke J et al. (2005) Salmon at River's End: the Role of the Estuary in the Decline and Recovery of Columbia River Salmon. US Department of Commerce. NOAA Technical Memorandum, NMFS-NWFSC-68.

Bradshaw WE, Holzapfel CM (2006) Evolutionary response to rapid climate change. Science, 312, 1477-1478.

Burger R, Lynch M (1995) Evolution and extinction in a changing environment: a quantitative-genetic analysis. Evolution, 49, 151-163.

Caudill CC, Daigle WR, Keefer ML et al. (2007) Slow dam passage in Columbia River salmonids associated with unsuccessful migration: delayed negative effects of passage obstacles or condition-dependent mortality? Canadian Journal of Fisheries and Aquatic Sciences, 64, 979-995.

Conover DO, Munch SB (2002) Sustaining fisheries yields over evolutionary time scales. Science, 297, 94-96.

Conover DO, Schultz ET (1997) Natural selection and the evolution of growth rate in the early life history: what are the trade-offs? In: Early Life History and Recruitment in Fish Populations (eds Chambers RC, Trippel EA), pp. 305-332. Chapman \& Hall, New York.

Cox GW (2004) Alien Species and Evolution: The Evolutionary Ecology of Exotic Plants, Animals, Microbes, and Interacting Native Species. Island Press, Washington, D.C.

Crossin GT, Hinch SG, Farrell AP et al. (2004) Energetics and morphology of sockeye salmon: effects of upriver migratory distance and elevation. Journal of Fish Biology, 65, 788-810.

Dietrich W (2003) Northwest Passage: The Mighty Columbia. University of Washington Press, Seattle.

Emmett RL, Krutzikowsky GK, Bentley P (2006) Abundance and distribution of pelagic piscivorous fishes in the Columbia River plume during spring/early summer 1998-2003: relationship to oceanographic conditions, forage fishes, and juvenile salmonids. Progress in Oceanography, 68, 1-27.

Ferguson JW, Matthews GM, McComas RL et al. (2005) Passage of Adult and Juvenile Salmonids through Federal Columbia River Power System Dams. US Department of Commerce. NOAA Technical Memorandum, NMFS-NWFSC-64.

Foley JA, DeFries R, Asner GP et al. (2005) Global consequences of land use. Science, 309, 570-574.

Fresh KL, Casillas E, Johnson LL, Bottom DL (2005) Role of the Estuary in the Recovery of Columbia River Basin Salmon and Steelhead: an Evaluation of the Effects of Selected Factors on Salmonid Population Viability. US Department of Commerce. NOAA Technical Memorandum, NMFS-NWFSC-69.

Fritts AL, Pearsons TN (2004) Smallmouth bass predation on hatchery and wild salmonids in the Yakima River, Washington. Transactions of the American Fisheries Society, 133, 880-895.

Geist DR, Abernethy CS, Blanton SL (2000) The use of electromyogram telemetry to estimate energy expenditure of adult fall Chinook salmon. Transactions of the American Fisheries Society, 129, 126135.

Gomulkiewicz R, Holt RD (1995) When does evolution by natural selection prevent extinction? Evolution, 49, 201-207.

Grant PR, Grant BR (1995) Predicting microevolutionary responses to directional selection on heritable variation. Evolution, 49, 241251. 
Greene CM, Beechie TJ (2004) Consequences of potential densitydependent mechanisms on recovery of ocean-type Chinook salmon (Oncorhynchus tshawytscha). Canadian Journal of Fisheries and Aquatic Sciences, 61, 590-602.

Groot C, Margolis L (1991) Pacific Salmon Life Histories. University of British Columbia Press, Vancouver, BC.

Gross MR (1987) Evolution of diadromy in fishes. American Fisheries Society Symposium, 1, 14-25.

Gustafson R, Waples RS, Myers JM et al. (2007) Pacific salmon extinctions: quantifying lost and remaining diversity. Conservation Biology, 21, 1009-1020.

Hallerman EM, ed. (2003) Population Genetics: Principles and Applications for Fisheries Scientists. American Fisheries Society, Bethesda, Maryland.

Hankin DG, Nicholas JW, Downey TW (1993) Evidence for inheritance of age of maturity in Chinook salmon (Oncorhynchus tshawytscha). Canadian Journal of Fisheries and Aquatic Sciences, 50, 347-358.

Hard JJ (1995) Genetic monitoring of life-history characters in salmon supplementation: problems and opportunities. American Fisheries Society Symposium, 15, 212-225.

Hard JJ (2004) Evolution of Chinook salmon life history under size-selective harvest. In: Evolution Illuminated: Salmon and Their Relatives (eds Hendry A, Stearns S), pp. 315-337. Oxford University Press, Oxford, UK.

Hard JJ, Elliott DG, Pascho RG et al. (2006) Genetic effects of ELISA-based segregation for control of bacterial kidney disease in Chinook salmon (Oncorhynchus tshawytscha). Canadian Journal of Fisheries and Aquatic Sciences, 63, 2793-2808.

Hard JJ, Hershberger WK (1995) Quantitative genetic consequences of captive broodstock programs for anadromous Pacific salmon (Oncorhynchus spp.). In: An Assessment of the Status of Captive Broodstock Technology for Pacific Salmon (eds Flagg TA, Mahnken CV), pp. 2-1-2-75. Final Report to the Bonneville Power Administration, Environment, Fish and Wildlife, Contract DE-AI79-93BP55064, Project no. 93-56.

Havel JE, Lee CE, Vander Zanden MJ (2005) Do reservoirs facilitate invasions into landscapes? Bioscience, 55, 518-525.

Heath DD, Devlin RH, Heath JW, Iwama JK (1994) Genetic, environmental and interaction effects on the incidence of jacking in Oncorhynchus tshawytscha (Chinook salmon). Heredity, 72, 146-154.

Hendry AP, Stearns SC, eds (2004) Evolution Illuminated: Salmon and Their Relatives. Oxford University Press, Oxford, UK.

High BC, Peery A, Bennett DH (2006) Temporary straying of Columbia River summer steelhead in coolwater areas and its effect on migration rates. Transactions of the American Fisheries Society, 135, 519-528.

Hilborn R, Quinn TP, Schindler DE, Rogers DE (2003) Biocomplexity and fisheries sustainability. Proceedings of the National Academy of Sciences, USA, 100, 6564-6568.

Hutchings JA (2004) Norms of reaction and phenotypic plasticity in salmonid life histories. In: Evolution Illuminated: Salmon and Their Relatives (eds Hendry A, Stearns S), pp. 154-174. Oxford University Press, Oxford, UK.

Hutchings JA (2005) Life history consequences of overexploitation to population recovery in Northwest Atlantic cod (Gadus morhua). Canadian Journal of Fisheries and Aquatic Sciences, 62, 824-832.

International Commission of Large Dams (ICOLD) (1998) World Register of Dams. www.icold-cigb.org. Paris.

Kareiva P, Marvier M, McClure MM (2000) Recovery and management options for spring/summer Chinook salmon in the Columbia River Basin. Science, 290, 977-979.
Keefer ML, Peery CA, Bjornn TC, Jepson MA, Stuehrenberg LC (2004) Hydrosystem, dam, and reservoir passage rates of adult Chinook salmon and steelhead in the Columbia and Snake rivers. Transactions of the American Fisheries Society, 133, 1413-1439.

Kingsolver JG, Hoekstra HE, Hoekstra JM et al. (2001) The strength of phenotypic selection in natural populations. American Naturalist, 157, 245-261.

Kinnison MT, Hendry AP (2001) The pace of modern life II: from rates of contemporary microevolution to pattern and process. Genetica, 112-113, 145-164.

Kinnison MT, Unwin MJ, Hendry AP, Quinn TP (2001) Migratory costs and the evolution of egg size and number in introduced and indigenous salmon populations. Evolution, 55, 1656-1667.

Kinnison MT, Unwin MJ, Quinn TP (2003) Migratory costs and contemporary evolution of reproductive allocation in male chinook salmon. Journal of Evolutionary Biology, 16, 1257-1269.

Loge FJ, Arkoosh MR, Ginn TR, Johnson LL, Collier TK (2005) Impact of environmental stressors on the dynamics of disease transmission. Environmental Science and Technology, 39, 7329-7336.

McCabe GT, Hinton SA, Emmett RL (1998) Benthic invertebrates and sediment characteristics in a shallow navigation channel of the lower Columbia River, before and after dredging. Northwest Science, 72, 116-126.

McClure MM, Holmes EE, Sanderson BL, Jordan CE (2003) A largescale, multispecies status assessment: anadromous salmonids in the Columbia River Basin. Ecological Applications, 13, 964-989.

McCully P (2001) Silenced Rivers: the Ecology and Politics of Large Dams. Enlarged and updated edition. Zed Press, London.

McDowall RM (1999) Different kinds of diadromy: different kinds of conservation problems. ICES Journal of Marine Science, 56, 410-413.

Merilä J, Sheldon BC, Kruuk LEB (2001) Explaining stasis: microevolutionary studies in natural populations. Genetica, 112-113, 199-222.

Merritt DM, Wohl EE (2002) Processes governing hydrochory along rivers: hydraulics, hydrology, and dispersal phenology. Ecological Applications, 12, 1071-1087.

Milner AM (1987) Colonization and ecological development of new streams in Glacier Bay National Park, Alaska. Freshwater Biology, 18 (1), 53-70.

Mobrand LE, Barr J, Blankenship L et al. (2005) Hatchery reform in Washington state: principles and emerging issues. Fisheries, 30 (6), 11-23.

Morgan CA, de Robertis A, Zabel RW (2005) Columbia River plume fronts. I. Hydrography, zooplankton distribution, and community composition. Marine Ecology Progress Series, 299, 19-31.

Mote PW, Parson EA, Hamlet AF et al. (2003) Preparing for climate change: the water, salmon, and forests of the Pacific Northwest. Climatic Change, 61, 45-88.

Muir WD, Marsh DM, Sandford BP, Smith SG, Williams JG (2006) Post-hydropower system delayed mortality of transported Snake River stream-type Chinook salmon: unraveling the mystery. Transactions of the American Fisheries Society, 135, 1523-1534.

National Research Council (1996) Upstream: Salmon and Society in the Pacific Northwest. National Academy Press, Washington, D.C.

Pearcy WG (1992) Ocean Ecology of North Pacific Salmonids. University of Washington Press, Seattle.

Petersen JH, Kitchell JF (2001) Climate regimes and water temperature changes in the Columbia River: bioenergetic implications for predators of juvenile salmon. Canadian Journal of Fisheries and Aquatic Sciences, 58, 1831-1841.

Petrosky CE, Schaller HA, Budy P (2001) Productivity and survival rate trends in the freshwater spawning and rearing stage 
of Snake River Chinook salmon (Oncorhynchus tshawytscha). Canadian Journal of Fisheries and Aquatic Sciences, 58, 1196-1207.

Postel SL, Daily GC, Ehrlich PR (1996) Human appropriation of renewable fresh water. Science, 271, 785-788.

Quinn TP (2005) The Behavior and Ecology of Pacific Salmon and Trout. American Fisheries Society, Bethesda, Maryland.

Quinn TP, Kinnison MT, Unwin MJ (2001) Evolution of Chinook salmon (Oncorhynchus tshawytscha) populations in New Zealand: Pattern, rate and process. Genetica, 112-113, 493-513.

Quinn TP, Unwin MJ, Kinnison MT (2000) Evolution of temporal isolation in the wild: genetic divergence in timing of migration and breeding by introduced Chinook salmon populations. Evolution, 54, 1372-1385.

Raymond HL (1979) Effects of dams and impoundments on migrations of juvenile Chinook salmon and steelhead from the Snake River, 1966-75. Transactions of the American Fisheries Society, 108, 505-529.

Regetz J (2003) Landscape-level constraints on recruitment of Chinook salmon (Oncorhychus tshawytscha) in the Columbia River basin, USA. Aquatic Conservation: Marine and Freshwater Ecosystems, 13, 35-49.

Rieman BE, Beamesderfer RC, Vigg S, Poe TP (1991) Estimated loss of juvenile salmonids to predation by northern squawfish, walleye, and smallmouth bass in John Day Reservoir, Columbia River. Transactions of the American Fisheries Society, 120, 448-458.

de Robertis A, Morgan CA, Schabetsberger RA et al. (2005) Columbia River plume fronts. II. Distribution, abundance and feeding ecology of juvenile salmon. Marine Ecology Progress Series, 299, 33-44.

Roby DD, Lyons DE, Craig DP, Collis K, Henk-Visser G (2003) Quantifying the effect of predators on endangered species using a bioenergetics approach: Caspian terns and juvenile salmonids in the Columbia River estuary. Canadian Journal of Zoology, 81, 250-265.

Roff DA (1988) The evolution of migration and some life history parameters in marine fishes. Environmental Biology of Fishes, 22, 133-146.

Sedell JR, Luchessa KJ (1982) Using the historical record as an aid to salmonid habitat enhancement. In: Acquisition and Utilization of Aquatic Habitat Inventory Information. Proceedings of a Symposium Held October 28-30, 1981, Portland, Oregon (ed. Armantrout NB), pp. 210-223. The Hague Publishing, Billings, Montana.

Smith SG, Muir WD, Hockersmith EE et al. (2003) Influence of river conditions on survival and travel time of Snake River fall Chinook salmon. North American Journal of Fisheries Management, 23, 939-961.

Steel EA, Lange IA (2007) Using wavelet analysis to detect changes in water temperature regimes at multiple scales: effects of multipurpose dams in the Willamette River basin. River Research and Applications, 23, 351-359.

Strauss SY, Lau JA, Carroll SP (2006) Evolutionary responses of natives to introduced species: what do introductions tell us about natural communities? Ecology Letters, 9 (3), 354-371.

Sullivan BE, PrahlFG, Small LF, Covert PA (2001) Seasonality of phytoplankton production in the Columbia River: a natural or anthropogenic pattern? Geochimica et Cosmochimica Acta, 65, 1125-1139.

Suryan RM, Craig DP, Roby DD et al. (2004) Redistribution and growth of the Caspian tern population in the Pacific coast region of North America, 1981-2000. Condor, 106, 777-790.

Taylor EB (1990) Phenotypic correlates of life-history variations in juvenile Chinook salmon, Oncorhynchus tshawytscha. Journal of Animal Ecology, 59, 455-468.

Taylor EB (1991) A review of local adaptation in Salmonidae, with particular reference to Pacific and Atlantic salmon. Aquaculture, 98, 185-207.
Tseng M (2007) Evolution in human-altered environment: a summit to translate science into policy. Molecular Ecology, 16, 3287-3288.

Vitousek PM, Mooney HA, Lubchenco J, Melillo JM (1997) Human domination of earth's ecosystems. Science, 277, 494-499.

Walsh MR, Munch SB, Chiba S, Conover DO (2006) Maladaptive changes in multiple traits caused by fishing: impediments to population recovery. Ecology Letters, 9, 142-148.

Waples RS, Drake J (2004) Risk-benefit considerations for marine stock enhancement: a Pacific salmon perspective. In: Stock Enhancement and Sea Ranching: Developments, Pitfalls and Opportunities (eds Leber KM, Kitada S, Blankenship HL, Svåsand T), 2nd edn, pp. 260-306. Blackwell, Oxford, UK.

Waples RS, Gustafson RG, Weitkamp LA et al. (2001) Characterizing diversity in salmon from the Pacific Northwest. Journal of Fish Biology, 59 (Supplement A), 1-41.

Waples RS, Teel DJ, Myers J, Marshall A (2004) Evolution of life history diversity in Chinook salmon: ancient lineages and parallel evolution. Evolution, 58, 386-403.

Ward DL, Petersen JH, Loch JJ (1995) Index of predation on juvenile salmonids by northern squawfish in the lower and middle Columbia River and lower Snake River. Transactions of the American Fisheries Society, 124, 321-334.

Williams RN (2006) Return to the River-Restoring Salmon to the Columbia River. Elsevier Academic Press, Burlington, Massachusetts.

Williams JG, Matthews GM (1995) A review of flow and survival relationships for spring and summer Chinook salmon, Oncorhynchus tshawytscha, from the Snake River basin. Fishery Bulletin, 93 (4), 732-740.

Williams JG, Smith SG, Zabel RW et al. (2005) Effects of the Federal Columbia River Power System on Salmon Populations. NOAA Technical Memorandum, NOAA-TM-NMFS-NWFSC-63.

Wood CC (1995) Life history variation and population structure in sockeye salmon. American Fisheries Society Symposium, 17, 195216.

Zabel RW, Achord S (2004) Relating size of individuals to juvenile survival within and among closely-related populations of Chinook salmon. Ecology, 85, 795-806.

Zabel RW, Scheuerell MD, McClure MM, Williams JG (2006) The interplay between climate variability and density dependence in the population viability of Chinook salmon. Conservation Biology, 20, 190-200.

Zabel RW, Wagner T, Congleton JL, Smith SG, Williams JG (2005) Survival and selection of migrating salmon from capturerecapture models with individual traits. Ecological Applications, 15, 1427-1439.

Zabel RW, Williams JG (2002) Selective mortality in Chinook salmon: what is the role of human disturbance? Ecological Applications, 12, 173-183.

One of Robin Waples' research interests is elucidating the evolutionary consequences of demographic and life history characteristics of fish populations. Rich Zabel studies the behavioural ecology of salmon, and he is particularly interested in placing observed behavior into the context of life history variability, both within and among populations and species. Mark Scheuerell studies how natural processes and anthropogenic factors interact to drive ecological dynamics. Much of his research focuses on the effects of climate variability and human activities on Pacific salmon populations and the aquatic ecosystems they inhabit. Beth Sanderson's research examines the implications of habitat changes for the conservation and recovery of threatened and endangered species. 